\title{
Perawatan Kaninus Maksila Ektopik dengan L Loop pada Alat Cekat Teknik Begg
}

\author{
Novarini Prahastuti*, Soekarsono Hardjono** dan Pinandi Sri Pudyani** \\ *Program Studi Ortodonsia PPDGS Fakultas Kedokteran Gigi Universitas Gadjah Mada \\ **Bagian Ortodonsia Fakultas Kedokteran Gigi Universitas Gadjah Mada \\ *Jl Denta no 1 Sekip Utara Yogyakarta, novarini2010@yahoo.co.id
}

\begin{abstract}
ABSTRAK
Gigi kaninus berperan penting dalam kestabilan serta perkembangan bentuk lengkung gigi, fungsi oklusi dan kesimetrisan profil wajah. Kaninus maksila walaupun ektopik dalam perencanaan perawatan ortodontik biasanya keberadaannya tetap dipertahankan, sehingga perlu dikoreksi. Koreksi kaninus maksila ektopik membutuhkan gaya untuk mengekstrusi sekaligus distalisasi gigi tersebut. Tekukan L loop pada wire dapat memberikan gaya ke arah vertikal - horisontal pada gigi secara bersamaan. Perawatan ortodontik dengan alat cekat teknik Begg dapat mengkoreksi malposisi gigi dengan gaya yang ringan tanpa membutuhkan waktu lama pada tahap I. Tujuan. memaparkan hasil perawatan kaninus maksila ektopik dengan L loop pada alat cekat teknik Begg. Perempuan 28 th mengeluhkan gigi-giginya berjejal dan gingsul sehingga mengganggu penampilan dan mengurangi rasa percaya diri. Diagnosis: Maloklusi Angle Klas I tipe skeletal klas II dengan retrognatik bimaksiler, bidental protrusif, shalow bite dan midline mandibula bergeser ke kanan $1 \mathrm{~mm}$ disertai crossbite, openbite serta malposisi gigi. Penanganan dilakukan menggunakan alat cekat teknik Begg dengan pencabutan 4 gigi premolar pertama. L loop pada wire dibuat untuk koreksi kaninus maksila ektopik pada tahap I perawatan Kesimpulan dari hasil perawatan menunjukkan perbaikan malrelasi, gigi berjejal, overjet dan overbite. L loop pada alat cekat teknik Begg dapat digunakan untuk mengkoreksi kaninus maksila ektopik dengan gaya yang ringan.
\end{abstract}

Maj Ked Gi; Desember 2013; 20(2): 208-216.

Kata kunci : kaninus maksila ektopik,L loop, teknik Begg.

\begin{abstract}
Treatment oN Ectopic Maxillary Canine using L loop WITH Begg Technique. The canine teeth play an important role in the stability and development of the dental arch form, function of occlusion and symmetry of facial profile. Although the maxillary canine is ectopic, in the orthodontic treatment plans its existence is usually maintained and thus needs to be corrected. The ectopic maxillary canine correction requires force to extrude and to distalize the teeth at once. $L$ loop of the archwire can give vertical horizontal force towards the teeth at the same time. The orthodontic treatment using a fixed appliance with Begg technique can correct malposition of teeth with a light force in shorter duration on the first step. The objective of the case report is to review the correction of an ectopic maxillary canine treatment with $L$ loops on fixed appliance Begg technique. A 28 year-old female patient complained about her crowded teeth at the upper and lower jaw and ectopic which interfere with her appearance and thus reduce her confidence. Diagnosis: Class I Angle Malocclusion, Class II skeletal type with bimaxillar retrognatic, protrusive bidental, shalow bite and mandible midline shifted to the right of $1 \mathrm{~mm}$ with crossbite, openbite and malposition of teeth. Treatment: use a fixed appliance of Begg technique with extraction of the 4 first premolars. L loop on the wire is made for the correction of ectopic maxillary canines in the first step of treatment. It is concluded that malrelasion, crowded, overjet and overbite can be corrected. The L loops on fixed appliance of Begg technique can be used to correct an ectopic maxillary canines with a light force.
\end{abstract}

Maj Ked Gi; Desember 2013; 20(2): 208-216.

Keywords: ectopic maxillary canines, L loops, Begg technique

\section{PENDAHULUAN}

Gigi kaninus berperan penting dalam kestabilan serta perkembangan bentuk lengkung gigi, estetika, fungsi oklusi dan kesimetrisan profil wajah'. Pada gerakan laterotrusif (working side) dari mandibula, kontak terjadi hanya pada gigi kaninus sehingga disebut sebagai 'penjaga' oklusi. Kaninus berperan melindungi gigi lainnya dari kekuatan torsi oklusal yang merugikan saat terjadi kontak ke dan dari oklusi sentrik (dan /atau relasi sentrik). Fungsi oklusi yang optimal merupakan salah satu tujuan perawatan ortodontik yang penting, karena apabila 
hal tersebut tidak tercapai berpotensi terjadinya gangguan pada temporomandibula (TMD) dan relapsnya hasil perawatan. ${ }^{2}$

Gigi disebut ektopik apabila tumbuh menyimpang dari posisi normal. Kaninus maksila bukal ektopik merupakan salah satu kasus yang sering ditemui dalam praktek ortodontik. Menurut Bedoya dan Fleming, ${ }^{3}$ prevalensi kaninus maksila permanen impaksi atau erupsi ektopik pada populasi umum sekitar 1-2\%. Etiologi kaninus ektopik meliputi faktor sistemik dan lokal. Faktor lingkungan berpengaruh selama kaninus bererupsi melalui jalurnya yang panjang dan berliku-liku. Gangguan terkait dengan folikel gigi yang tidak erupsi sehingga mempengaruhi arah erupsi dan berkontribusi terhadap perpindahan kaninus maksila. Kaninus ektopik dikaitkan dengan komponen genetik dengan pola genetik multifaktorial yang diwariskan. Hal tersebut menjelaskan bagaimana kejadian tersebut dapat terjadi berulang dalam beberapa keluarga. Etiologi kaninus ektopik lainnya meliputi kekurangan ruang untuk erupsi, premature loss kaninus sulung, ankilosis, pembentukan neoplastik, dilaserasi akar dan posisi akar insisivus lateral yang abnormal. ${ }^{3}$

Kaninus maksila walaupun ektopik dalam perencanaan perawatan ortodontik biasanya keberadaannya tetap dipertahankan sehingga perlu dikoreksi. Perawatan ortodontik dilakukan umumnya karena alasan estetika, namun diagnosis perawatannya memerlukan pertimbangan adanya internal atau eksternal resorpsi akar gigi yang berdekatan sebagai dampak perawatan lanjutan. ${ }^{3}$ Koreksi gigi maksila ektopik membutuhkan gaya ringan sebesar 20-60 gr. Hal penting yang harus diperhatikan sebelum dliakukan perawatan adalah tersedianya ruang yang memadai untuk reposisi gigi kaninus yang akan dikoreksi. ${ }^{4}$ Koreksi kaninus maksila ektopik dibukal membutuhkan gaya untuk mengekstrusi sekaligus distalisasi gigi tersebut. Tekukan L loop pada wire dapat memberikan gaya ke arah vertikal-horisontal pada gigi tersebut secara bersamaan. Desain loop tersebut akan mengurangi kekakuan rentangan dan mengoptimalkan fleksibilitas archwire. Penggunaan diameter kawat yang kecil dengan pemilihan jenis kawat yang bersifat lenting akan memberikan gaya yang ringan. ${ }^{5}$
Pergerakan gigi harus dilakukan dengan gaya ringan. Klinisi harus memahami penerapan besar kekuatan yang tepat, khususnya pada saat pengaturan awal gigi (initial alignment). Menurut Reitan's, pemberian gaya yang terlalu besar pada gigi menyebabkan terbentuknya hialinisasi ligamentum periodontal sehingga memperlambat pergerakan gigi. ${ }^{5}$ Pemakaian kekuatan/ gaya optimal selama perawatan ortodontik akan memberikan hasil perawatan yang memuaskan, gerakan gigi yang cepat dengan meminimalkan ketidak nyamanan dan kerusakan struktur jaringan yang berdekatan melalui gaya kontinyu dan ringan. ${ }^{6}$ Menurut Hixon, ${ }^{6}$ gaya ringan tersebut dapat dihasilkan dari gerakan tipping yang memberi tekanan besar pada puncak alveolar.

Perawatan ortodontik teknik Begg bertujuan memperbaiki maloklusi dengan karakteristik gerakan tipping gigi. ${ }^{7}$ Kekuatan fisiologis ringan serta kontinyu menghasilkan pergerakan gigi yang sangat cepat pada teknik Begg. Gaya tersebut dihasilkan dari pemakaian kawat yang lenting dan gaya ringan dari elastik. ${ }^{8}$ Braket Begg memungkinkan gerakan tipping tanpa friksi karena hanya ada one point kontak antara braket dan round wire. ${ }^{7}$ Perawatan teknik Begg dibagi menjadi 3 tahap. Pada tahap I, dilakukan general alignment dan koreksi lengkung gigi, mengkoreksi kelainan bukolingual dan rotasi (unravelling), koreksi kelainan vertikal (levelling), pengurangan overbite dan retraksi insisivus atas sehingga dicapai relasi edge to edge terhadap insisivus bawah. ${ }^{8}$ Tahap II bertujuan untuk penutupan ruang sisa pencabutan (space closing) dan tahap III bertujuan memperbaiki inklinasi aksial, mesiodistal dan labiolingual. Keistimewaan teknik Begg yaitu perawatan dilakukan secara komprehensif sehingga koreksi profil wajah menjadi cepat karena retraksi gigi anterior terjadi bersamaan dengan perubahan oklusi semua gigi dan bite opening. ${ }^{7}$

Artikel ini bertujuan memaparkan hasil perawatan kaninus maksila ektopik dengan L loop pada alat cekat teknik Begg yang bekerja dengan gaya ringan-kontinyu serta pengaruhnya terhadap resiko resorpsi akar gigi insisivus lateral dan jaringan pendukung gigi. 


\section{STUDI KASUS}

Pasien perempuan, umur 28 tahun datang ke klinik Ortodonsia RSGM Prof. Soedomo dengan keluhan gigi-gigi depan atas dan bawah berjejal, "gingsul" serta dua gigi depan atas maju sehingga mengganggu penampilan. Pemeriksaan subyektif menjelaskan bahwa pada periode gigi bercampur, pergantian gigi pasien yang goyah tanggal dengan sendirinya dan pernah kesundulan pada gigi depan atas serta gigi belakang bawah. Gigi-gigi dirasakan mulai berjejal sejak klas 3 SD dan gigi depan atas dirasakan mulai maju sejak SMP. Pada riwayat keluarga, ayah dan ibu pasien mempunyai susunan gigi yang rapi namun saudara kandungnya juga mempunyai susunan gigi yang berjejal. Kemungkinan etiologi maloklusi pasien ini, salah satunya akibat adanya gigi-gigi sulung yang persistensi pada masa gigi bercampur.

Pemeriksaan ekstraoral menunjukkan profil yang cembung, tonus otot bibir normal, posisi bibir ketika istirahat nornal tertutup (gambar 1). Pemeriksaan intra oral memperlihatkan kebersihan mulut sedang, ukuran lidah sedang, bentuk lengkung gigi atas dan lengkung gigi bawah parabola asimetris (Gambar 2)
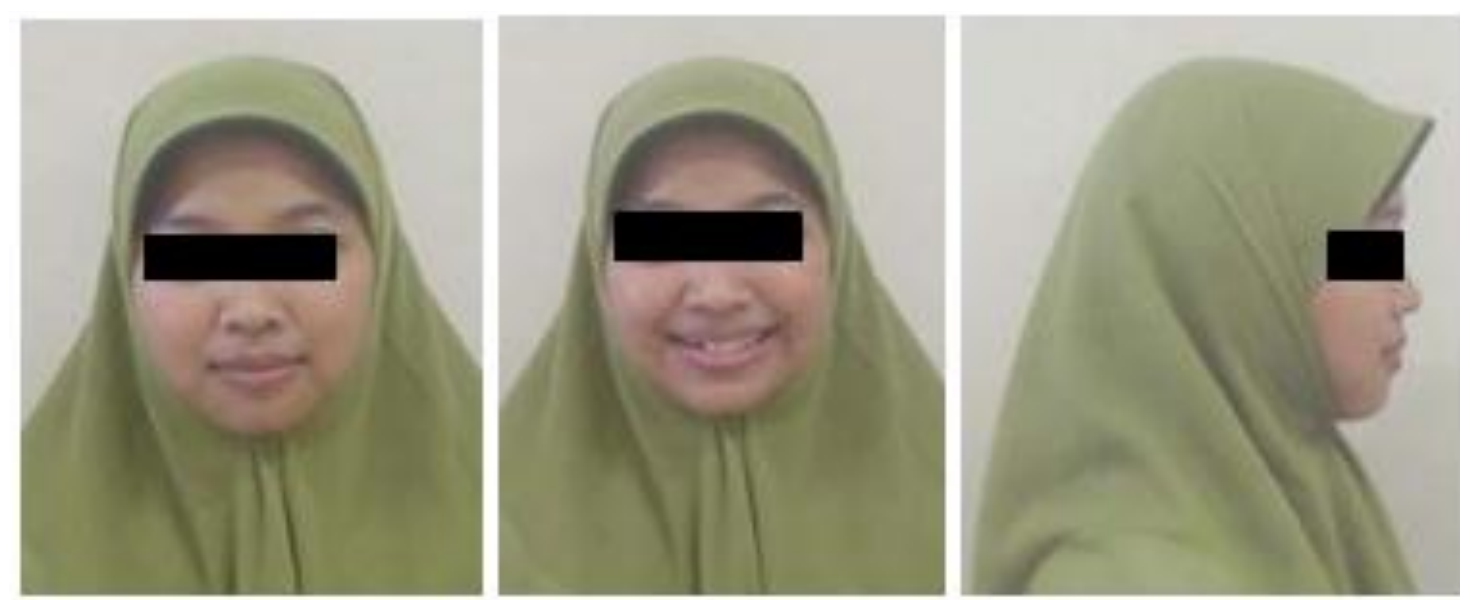

Gambar 1. Foto ekstraoral sebelum perawatan
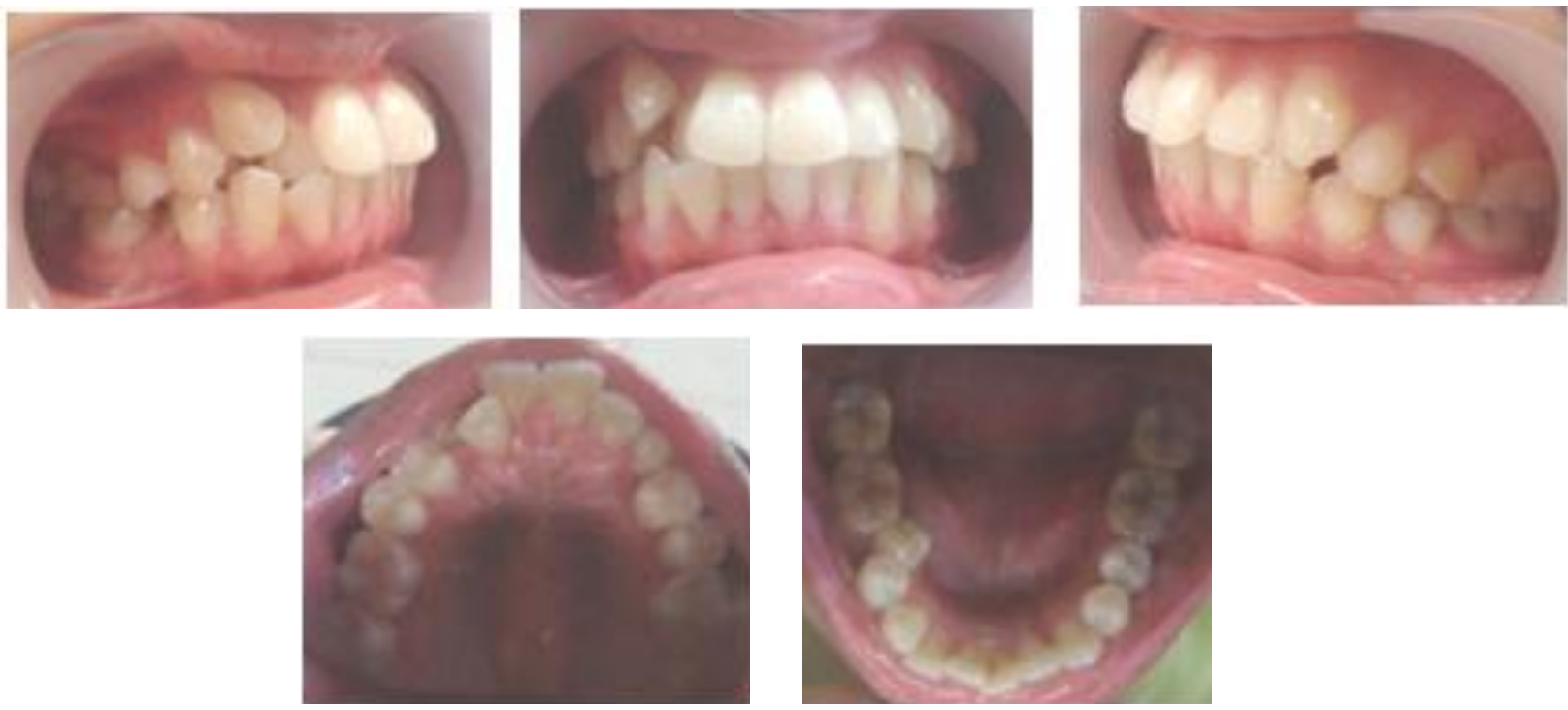

Gambar 2. Foto intraoral sebelum perawatan 
Susunan gigi-gigi anterior rahang atas-bawah berjejal disertai openbite pada regio 13 terhadap 43, crossbite.anterior pada regio 12 terhadap 32, 33 serta crossbite posterior pada regio 15 terhadap 45 , dan regio 25 terhadap 35 . Overjet $2,6 \mathrm{~mm}$ dan overbite $1,4 \mathrm{~mm}$. Hubungan gigi molar pertama kanan dan kiri Klas I Angle. Hubungan gigi kaninus kiri Klas II sedangkan pada sisi kanan, gigi kaninus maksila ektopik (mesiolabioversi-infraoklusi). Garis tengah rahang bawah terhadap rahang atas tidak segaris, garis interinsisivi sentral terhadap garis tengah rahang segaris. Midline RB bergeser ke kanan $1 \mathrm{~mm}$.

Berdasarkan hasil analisis sefalometri pasien disimpulkan maloklusi klas II skeletal dengan retrognatik bimaksiler dan bidental protrusif. Analisis jaringan lunak menunjukkan bibir bawah terletak $2 \mathrm{~mm}$ lebih ke depan dari garis Steiner (protrusif). Diagnosis kasus pasien yaitu maloklusi Angle Klas I, tipe skeletal Klas II dengan retrognatik bimaksiler dan bidental protrusif, disertai shalow bite dan midline RB bergeser ke kanan $1 \mathrm{~mm}$, malrelasi dan malposisi gigi individual.

Rencana perawatan bertujuan memperbaiki gigi berjejal, openbite, cross bite, koreksi ovebite dan shif midline dengan menggunakan alat cekat teknik Begg. Berdasarkan perhitungan determinasi lengkung dan set up model Kesling setelah RA dan RB diretraksi sebesar $2 \mathrm{~mm}$ dan midline RB dikoreksi dengan bergeser ke kiri $1 \mathrm{~mm}$, kebutuhan ruang pada RA untuk kasus ini adalah sebesar 13,1 mm sedangkan pada RB dibutuhkan ruang sebesar 9,4 $\mathrm{mm}$. Kekurangan ruang yang dibutuhkan didapatkan dengan pencabutan empat gigi premolar pertama.. Koreksi gigi kaninus maksila kanan ektopik dilakukan mulai tahap I perawatan menggunakan L loop archwire di mesial gigi 13, sedangkan untuk koreksi malposisi gigi lainnya menggunakan multiple vertical loop archwire (Gambar 3 dan 4)
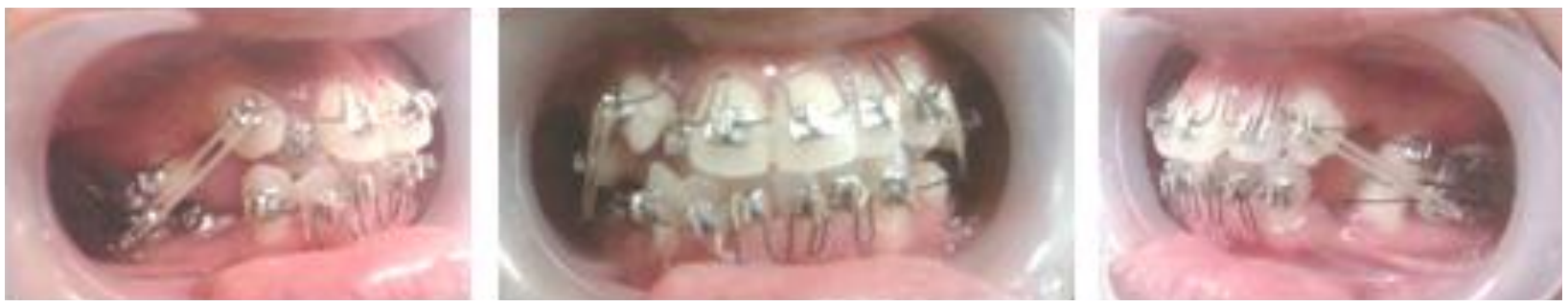

Gambar 3. Foto intraoral pada saat insersi alat ortodontik dengan teknik Begg

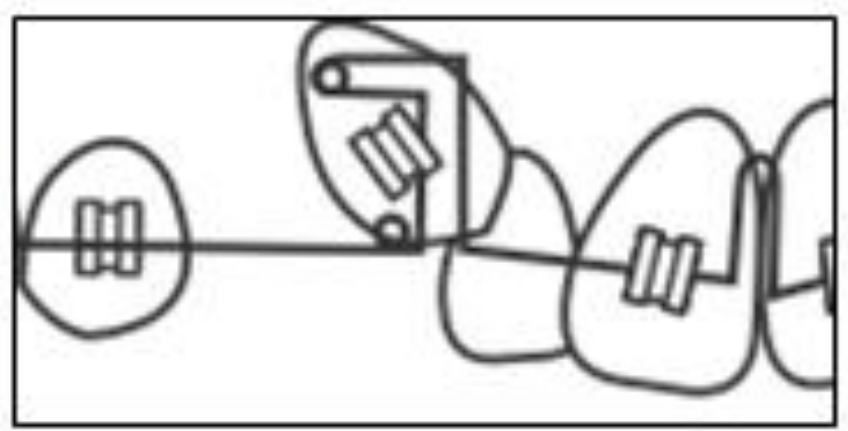

(A)

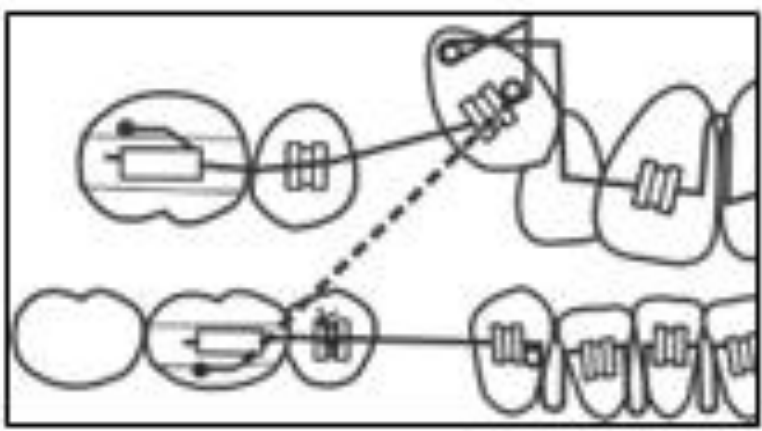

(B)

Gambar 4. (A) L loop archwire pada saat pasif; (B) L loop archwire pada saat aktif (laporan rencana perawatan kasus, penulis) 
Tahap perawatan disusun berdasarkan tahaptahap pada metode teknik Begg. Tujuan tahap I perawatan teknik Begg antara lain general alignment, mengatur letak gigi dengan koreksi buko-lingual (unravelling), memperbaiki ketidakteraturan dalam arah vertikal (levelling) dan koreksi relasi gigi anterior menjadi edge to edge.

Perawatan dimulai dengan menggunakan busur australian wire berdiameter 0,014", setelah dilakukan pencabutan 4 gigi premolar pertama. Gigi-gigi rahang atas dan rahang bawah dilakukan levelling dan unravelling dengan vertikal loop archwire di antara gigi 12-11,11-21, 21-22, 22-23, 43-42, 42-41, 41-31, 31-32 dan 32-33 yang dilengkapi dengan circle hook di mesial gigi kaninus RA dan RB. Koreksi gigi 13 ektopik dilakukan dengan membuat helical L loop archwire di mesial gigi 13, yang dilengkapi dengan circle hook di distal braket 13 tetapi saat dipasang diletakkan di mesial gigi tersebut. Pada saat insersi alat ortodontik dengan teknik Begg dilakukan by pass pada gigi 15, 25 dan 35. Gigi 45 diligasi dengan ligature wire untuk koreksi linguoversi. Pada archwire rahang atas ataupun rahang bawah dibuat anchorage bend sebesar $15^{\circ}$ di mesial gigi molar pertama (Gambar 3 dan 4).

Pemakaian karet elastik intermaksiler 5/16" 2 oz yang diganti setiap hari, mulai digunakan sejak tahap I. Kekuatan karet elastik tersebut mengaktifkan $\mathrm{L}$ loop dan vertikal loop arch wire pada gigi anterior yang malposisi sehingga terjadi general alignment. Pada akhir tahap I jika general alignment telah tercapai, retraksi gigi anterior RA dan RB dilakukan dengan mengganti main wire menjadi plain archwire 0,016" yang dilengkapi dengan circle hook pada mesial kaninus. Hal tersebut diikuti dengan koreksi malposisi gigi menggunakan rotating/ uprighting auxillary spring (Gambar 5)

Tahap II perawatan teknik Begg dilakukan space closing dengan plain archwire 0,018" dengan dilengkapi dengan anchorage bend $15^{\circ}$ pada mesial molar pertama, circle hook pada mesial kaninus serta pemakaian karet elastik intramaksiller dan karet elastik intermaksiller Klas II untuk mempertahankan relasi insisivus edge to edge.

Tahap III perawatan teknik Begg bertujuan memperbaiki inklinasi aksial gigi-gigi RA dan RB (root paralleling) menggunakan plain archwire $0,020^{\prime \prime}$ dengan anchorage bend $15^{\circ}$ di mesial molar pertama, circle hook pada mesial braket kaninus, uprighting spring untuk koreksi gigi yang tilting, palatal/ lingual root torque untuk root paralleling gigi anterior RA dan RB, serta elastik intermaksiler klas II 5/16" 2 oz untuk mempertahankan overbite dan overjet.

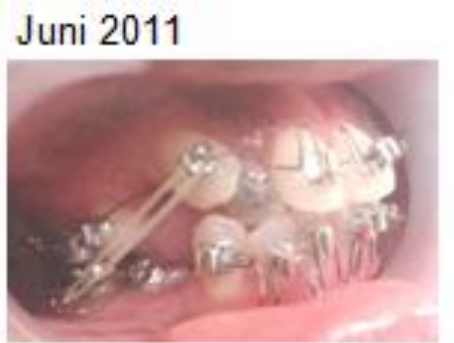

Juli 2011

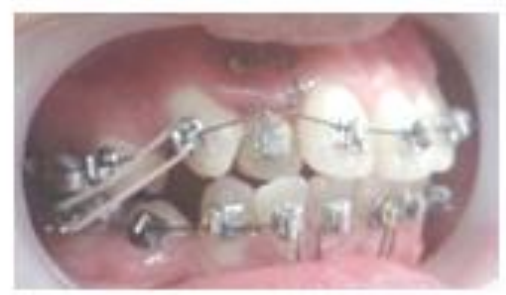

\section{September 2011}

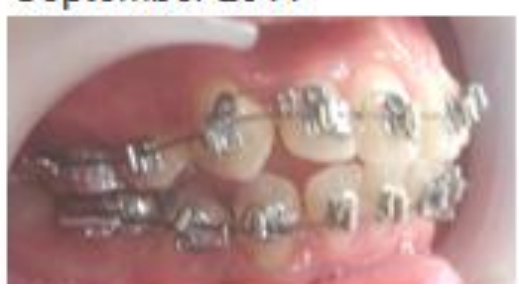

April 2012

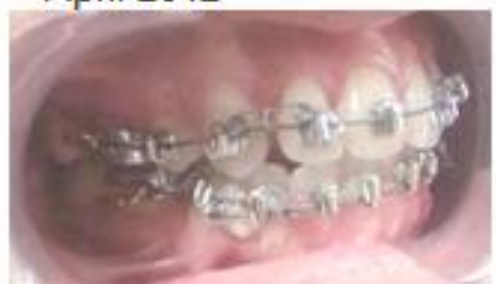

Gambar 5. Koreksi kaninus ektopik dengan teknik Begg pada tahap I 

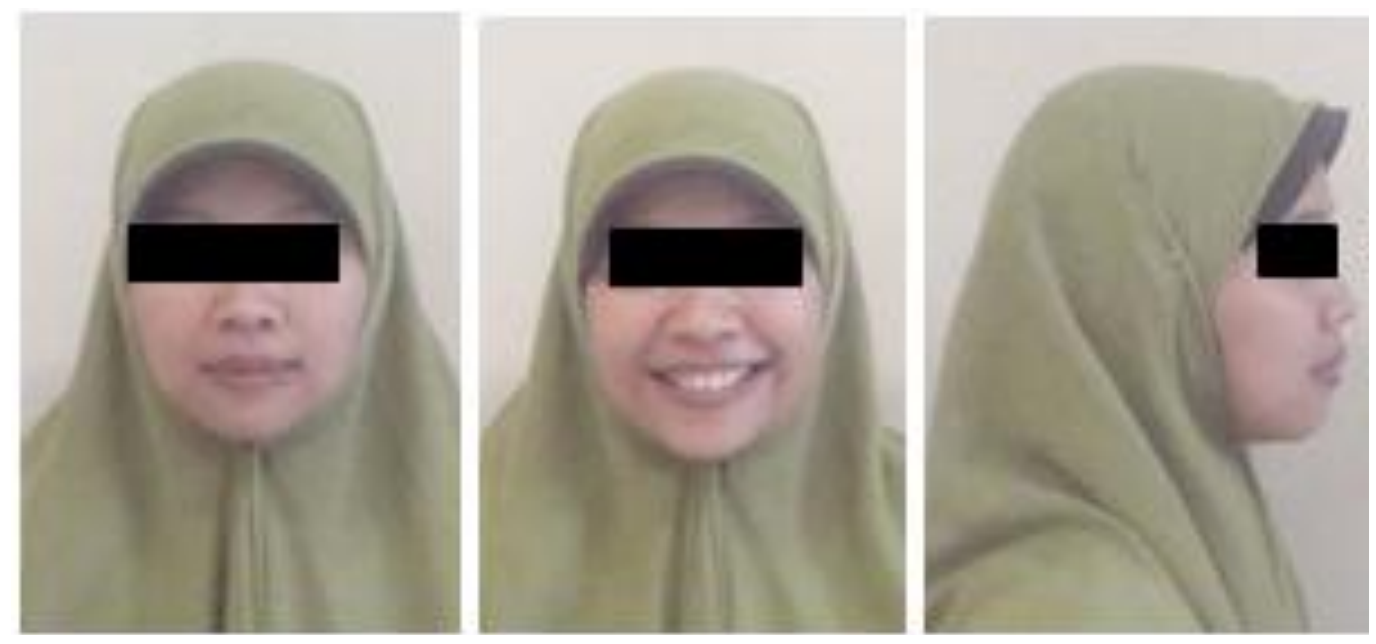

Gambar 6. Foto ekstraoral setelah 1 tahun perawatan
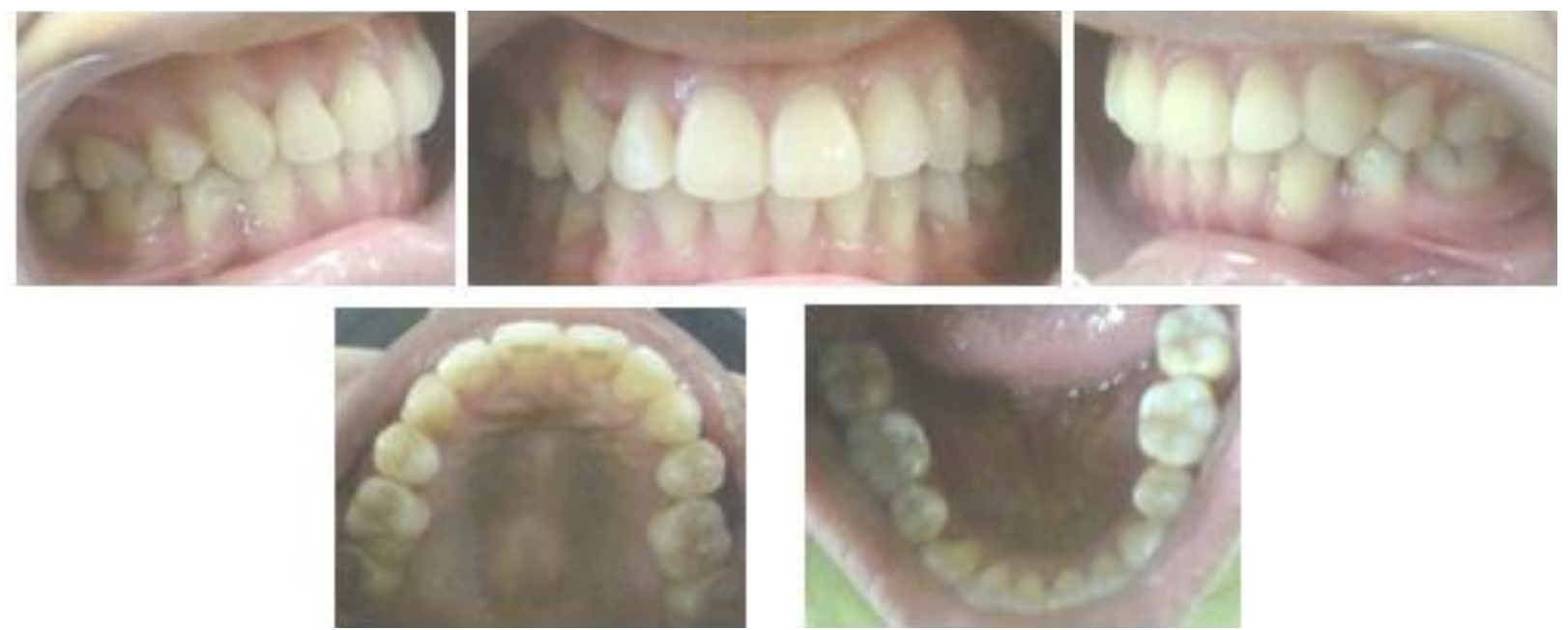

Gambar 7. Foto intraoral sesudah perawatan

Perawatan tahap I teknik Begg dilakukan selama 10 bulan. Pemakaian L loop dan vertikal loop archwire dalam 2 bulan, menghasilkan unreaveling dan leveling gig-gigi RA dan RB. Gigi 13 yang ektopik terekstrusi dan terdorong ke distal diikuti koreksi gigi 12 yang palatoversi. Koreksi dilanjutkan dengan menggunakan plain australian wire 0,016" selama 8 bulan, menghasilkan retraksi gigi anterior disertai koreksi malposisi gigi. Penegakan gigi 13 yang masih mesioversi menggunakan uprighting auxillary spring dilakukan sebelum retraksi gigi-gigi anterior.

Perawatan tahap II teknik Begg dilakukan selama 1 bulan. Retraksi gigi-gigi anterior pada tahap
I, masih menyisakan ruang di bekas pencabutan gigi premolar pertama yaitu di distal gigi kaninus sebesar 0,9-3,8 mm Gigi-gigi posterior dimesialisasikan untuk menutup sisa ruang tersebut dengan reverse anchorage di gigi anterior serta menggunakan karet elastik intramaksiller dan karet elastik intermaksiller klas II. Perawatan tahap III teknik Begg dilakukan selama 2 bulan, didapatkan hasil perbaikan inklinasi aksial gigi-gigi anterior.dan posrterior.

Pasien ini sudah selesai perawatan ortodontik teknik Begg dengan masa perawatan selama 1 tahun, kemudian dilanjutkan pemakaian Hawley retainer RA dan RB (Gambar 6 dan 7). Pada akhir 
Tabel 1. Pengukuran sefalometri sebelum dan sesudah perawatan

\begin{tabular}{lccc}
\hline Pengukuran & Nilai Normal & Sebelum Perawatan & Sesudah Perawatan \\
\hline SNA & $82^{\circ}$ & $79^{\circ}$ & $81^{\circ}$ \\
SNB & $80^{\circ}$ & $74^{\circ}$ & $75^{\circ}$ \\
ANB & $2^{\circ}$ & $5^{\circ}$ & $6^{\circ}$ \\
Inter I-I & $130^{\circ}$ & $110^{\circ}$ & $135^{\circ}$ \\
IMPA & $81,5^{\circ}-97^{\circ}$ & $105^{\circ}$ & $93^{\circ}$ \\
Overbite & $2-4 \mathrm{~mm}$ & $1,4 \mathrm{~mm}$ & $2,3 \mathrm{~mm}$ \\
Overjet & $2-4 \mathrm{~mm}$ & $2,4 \mathrm{~mm}$ & $2,8 \mathrm{~mm}$ \\
\hline
\end{tabular}

perawatan terjadi perubahan inklinasi insisivus mandibula menjadi semakin tegak (IMPA $105^{\circ}$ menjadi $\left.93^{\circ}\right)$, peningkatan sudut interinsisisal $\left(110^{\circ}\right.$ menjadi $135^{\circ}$ ), retraksi gigi-gigi anterior sehingga profil wajah pasien semakin harmounis. Hasil perawatan didapatkan koreksi gigi kaninus maksila ektopik dan gigi berjejal, perbaikan overbite $(1,4$ $\mathrm{mm}$ menjadi 3,2 $\mathrm{mm}$ ) -overjet serta terkoreksinya malrelasi openbite anterior dan crossbite anteriorposterior (Tabel 1)

\section{PEMBAHASAN}

Kaninus maksila ektopik merupakan kasus yang mungkin akan sering kita jumpai dalam praktek. Penetapan diagnosis dimulai dengan pengamatan klinis pasien. Tanda pertama ektopik nampak jika kaninus permanen pasien tidak bererupsi sesuai usia kronologis perkembangan gigi rata-rata. ${ }^{3}$ Periode erupsi normal kaninus maksila biasanya terjadi pada usia 11-13 tahun. ${ }^{1}$

Penanganan yang tepat pada pasien dengan gigi kaninus maksila ektopik menjadi tugas dokter gigi dan dalam menentukan perencanaan perawatan memerlukan tindakan yang berhati-hati. Evaluasi klinis pasien mempertimbangkan jumlah ruang dalam lengkung gigi untuk erupsi kaninus ektopik, morfologi dan posisi gigi yang berdekatan, kontur tulang, mobilitas gigi, dan penilaian radiografi untuk menentukan posisi kaninus yaitu apeks akar, mahkota, dan arah aksis gigi. Keputusan pencabutan premolar pertama pada pasien ini didasarkan pada pertimbangan estetis, fungsional, dan kestabilan hasil perawatan. ${ }^{7} \mathrm{Hal}$ tersebut sesuai dengan pernyataan Falahata ${ }^{9}$ bahwa tindakan ortodontik untuk reposisi kaninus biasanya membutuhkan ekstraksi premolar.

Perawatan kasus pasien ini dengan teknik Begg memberikan hasil yang cepat dengan gaya ringan. Keadaan gigi berjejal dan adanya kaninus maksila ektopik yang merupakan keluhan utama pasien dapat segera terkoreksi dalam 2 bulan pada tahap I perawatan. Pemakaian Australian wire berdiameter kecil $(0,014$ ") yang bersifat sangat lenting, bentuk slot dan ukuran braket Begg yang apabila dipasang hanya berkontak satu titik kontak menyebabkan jarak interbraket makin lebar, penambahan desain L loop dan vertikal loop pada archwire menambah kelentingan sehingga perawatan dilakukan dengan kekuatan fisiologis ringan serta kontinyu dan menghasilkan pergerakan gigi yang sangat cepat. Hal tersebut sesuai menurut Waters, ${ }^{5}$ bahwa kelentingan rentang archwire tergantung pada pada diameter dan sifat elastis kawat, jarak interbracket dan dimensi/ ukuran braket, dan desain archwire.

Pada tahap I perawatan, L loop archwire memberikan gaya vertikal-horisontal pada gigi 13 ektopik yang dikoreksi. Circle hook pada rahang atas kanan yang dibuat di distal braket 13 , namun saat pemasangan diletakkan di mesial gigi 13 akan 
mendorong gigi tersebut ke distal sekaligus ekstrusi sehingga membuka ruang untuk gigi insisivus lateral yang awalnya palatoversi. Karet elastik klas II yang digunakan mulai awal tahap I akan mengaktifkan kerja $L$ loop serta vertikal loop archwire sehingga membantu tahap leveling -unreavelling berjalan cepat dengan gaya ringan.

Perawatan ortodontik kaninus maksila ektopik sering dikaitkan dengan resorpsi akar gigi insisivus lateral sebelahnya. Hal tersebut bervariasi berdasarkan posisi gigi kaninus, kekurangan ruang dan ada tidaknya pemandu erupsi, tahap perkembangan gigi sebelahnya, lokasi dan keparahan resorpsi akar. Resorpsi akar gigi insisivus atas tetap yang berdekatan dengan kaninus ektopik, dapat disebabkan oleh tekanan erupsi kaninus yang melekat saat reposisi, maupun adanya kontak fisik antara akar gigi insisivus dengan mahkota kaninus. ${ }^{9}$

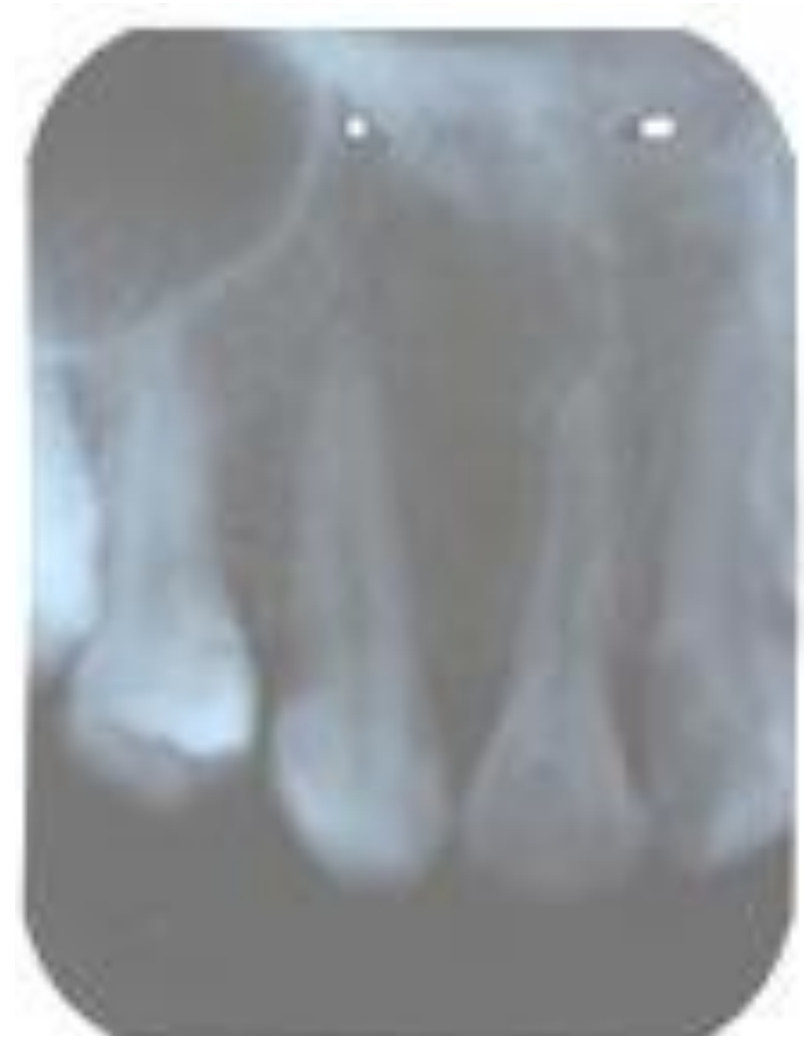

Gambar 8. Rontgen periapikal pada gigi 13 dan 12 setelah 1 tahun pemakaian retainer
Pada pasien ini gambaran rontgen periapikal pada gigi 13 dan 12 setelah 1 tahun pemakaian retainer, menunjukkan terbentuknya jaringan pendukung gigi yang sehat tanpa ada resorpsi apeks gigi yang di koreksi menggunakan L loop pada teknik Begg (Gambar 8).

\section{KESIMPULAN}

Perawatan ortodontik cekat teknik Begg menggunakan australian archwire yang lenting dengan penambahan L loop dapat digunakan untuk mengkoreksi kaninus maksila ektopik dengan gaya ringan serta relatif cepat pada tahap I. Hal tersebut menggambarkan prinsip biomekanik sederhana dan cara mudah untuk membawa kaninus maksila ektopik kedalam lengkung gigi yang ideal. Pemakaian gaya ringan dan kontinyu dari hasil kerjasama L loop archwire berdiameter kecil serta karet elastik Klas II bergaya ringan pada circle hook di mesial kaninus maksila ektopik, memberikan hasil perawatan memuaskan tanpa menyebabkan kerusakan struktur jaringan pendukung gigi maupun resorpsi akar gigi insisivus lateral. Kesadaran, motivasi dan kerjasama pasien dalam perawatan ortodontik ini sangat menentukan keberhasilan perawatan.

\section{DAFTAR PUSTAKA}

1. Prakash A, Gupta SD, Rai S, Arora A, Jain S. Australian helical archwire-helping hand for canine impaction. Univers.J. Med. Dent. 2012; 7(1): 076-078.

2. Rinchuse DJ, Kandasamy S, Sciote J. Contemporary and evidencede-based view of canine protected occlusion. Am J.Orthod. 2007; 132(1): 90-132.

3. Sachan A, Chaturvedi TP. Orthodontic management of buccaly erupted ectopic canine withtwo case reports. Contemp.Clin Dent. 2012; 3(1): 123-128.

4. Patrick F, Mcsherry BA. The ectopic maxillary canine : A Review. BJO. 1998; 25: 209-21.

5. Waters NE, Houston WJ, Stephen CD. The characterization of arch wires for the initial alignment of irregular teeth. Am.J.Orthod. 1981; 79(4): 375-389. 
6. Bisol GK, Rocha R. Laboratorial study of the cuspid"s retraction timming and tipping effect, during space closure, using the segmented ach technique. Dental Press J.Orthod. 2010; 15(1): 53-64.

7. Cadman GR. A Vade Mecum for The Begg Technique: Technical Principles. Am J Orthod Dentofacial Orthop. 1975; 67(5): 447-512.
8. Salzmann JA. Orthodontics in Daily Practice. J.B. Lippincott company; 1974.

9. Falahata B, Ericsonb S, D’Amico RM, Bjerklind K. Incisor root resorption due to ectopic maxillary caninesa long-term radiographic follow-up. Angle Orthodontist. 2008; 78(5): 778-784. 